\title{
Investigation of kaolinite dehydroxylations is still interesting
}

\author{
Igor Štubňa - Gabriel Varga - Anton Trník \\ Physics Department, Constantine the Philosopher University \\ istubna@ukf.sk-gvarga@ukf.sk
}

\begin{abstract}
A kaolinitásvány dehidratációja kutatásának aktuális kérdései
A kaolinit metakaolinitté történö átalakulásának folyamata mind a mai napig számos kérdést vet fel annak ellenére, hogy maga a dehidratációs folyamat látszólag kellöen ismert és feltárt. A szerzők munkájukban ismertetik a kaolinitásvány kémiai összetételét, kristályszerkezeti felépitését, a rácspontok távolságát és szögeit.

A tanulmány részletesen foglalkozik a dehidratációval mint folyamattal, átfogó képet adva a kaolinitásványok dehidratációjáról alkotott tudományos tézisek fejlödéstörténetéröl - részletesen kitérve a lejátszódó kémiai ,,bomlási” reakciókra, a kristályszerkezet átalakulására és a kristályviz eltávolitásához, dehidratációjához szükséges energiaigényre. Megállapítja, hogy
\end{abstract}

a kaolinit rácshibái jelentösen befolyásolják-, ,gyorsitják”-a dehidratációs folyamatot; míg tökéletes, tömör kristályok esetén a dehidratációhoz szükséges hömérséklet elérheti akár a 850 $950^{\circ} \mathrm{C}$-ot is! A tanulmány megvizsgálja és elemzi a dehidratáció eredményeként létrejövö metakaolinit szerkezeti struktúráját, miközben megpróbál magyarázatot adni a $950^{\circ} \mathrm{C}$-nál lejátszódó - zsugorodással együttjáró - exoterm reakciókra.

Végezetül a szerzők megpróbálják összefoglalni (Conclusion) a kaolinitásvány dehidratációjának feltételeit-elemezve a dehidratációs folyamat során lejátszódó jelenségeket is. Az elvégzett elméleti vizsgálódások és laboratóriumi mérések eredményei alapján megállapitják, hogy a dehidratációs mechanizmus nem irható le egyetlen modellel, amely érvényes lenne a teljes dehidratációs hömérséklet-tartományra.

\section{Introduction}

Although the reactions in kaolinite during its heating have been investigated for many years, using several techniques (XRD, DTA, TG, thermodilatometry, gas chromatographic analysis, transmission electron microscopy, infrared spectroscopy), controversy about dehydroxylation continue to exist. A process of elimination of the $\mathrm{OH}$ groups from the kaolinite structure (dehydroxylation) is not fully understood up to now. The crystalization of metakaolinite and the crystallographic orientation relationships of the kaolinite - metakaolinite reaction remain controversal [1] as well as a range of opinions on the mechanism of dehydroxylation.

\section{Kaolinite}

The theoretical formula for kaolinite is $\mathrm{Si}_{2} \mathrm{Al}_{2} \mathrm{O}_{5}(\mathrm{OH})_{4}$ (other formulae are $\mathrm{Al}_{2} \mathrm{O}_{3} \cdot 2 \mathrm{SiO}_{2} \cdot 2 \mathrm{H}_{2} \mathrm{O}$ and $\mathrm{Al}_{2} \mathrm{O}_{7} \mathrm{Si}_{2} \cdot 2 \mathrm{H}_{2} \mathrm{O}$ ), which represent a molecular weight of 258.071. Kaolinite has a 1:1 sheet structure composed of $\mathrm{SiO}_{4}$ tetrahedral sheets and $\mathrm{Al}(\mathrm{O}, \mathrm{OH})_{6}$ octahedral sheets (or, expressed in other way, $\left[\mathrm{Si}_{2} \mathrm{O}_{5}\right]^{2-}$ sheet and $\left[\mathrm{Al}_{2}(\mathrm{OH})_{4}\right]^{2+}$ sheet) with pseudo-hexagonal symmetry [2]. A structure of kaolinite is depicted in many textbooks and articles, e. g. $[1,4,10]$, one from possible models is shown in Fig. 1. The sheets are created from planes, which are occupied as follows: $\mathrm{O}_{6}-\mathrm{Si}_{4}-\mathrm{O}_{4}-(\mathrm{OH})_{2}-\mathrm{Al}_{4}-(\mathrm{OH})_{6}$. The morphology of the kaolin crystals is plate-like. The c-axis of the kaolinite crystal is perpendicular to the basal plane. A crystal system of the kaolinite is triclinic, the space group is $\mathrm{P} 1$, and lattice parameters are $a=0.515 \mathrm{~nm}, b=0.895 \mathrm{~nm}, c=0.740 \mathrm{~nm}$, $\alpha=91,68^{\circ}, \beta=104,87^{\circ}, \gamma=89,9^{\circ}$ [3]. An ideal cell of the kaolinite is electrically neutral. Its crystallochemical formula is $\mathrm{Si}_{4} \mathrm{Al}_{4} \mathrm{O}_{10}(\mathrm{OH})_{8}$ and the theoretical composition expressed by oxides is $46.64 \% \mathrm{SiO}_{2}, 39.60 \% \mathrm{Al}_{2} \mathrm{O}_{3}$ and $13.96 \% \mathrm{H}_{2} \mathrm{O}[4]$.

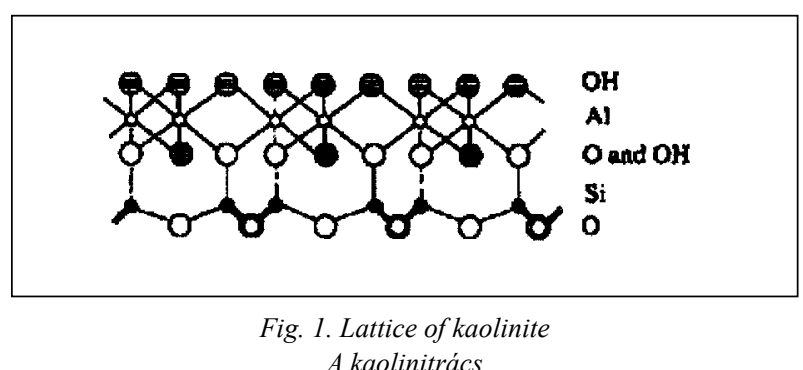

\section{Dehydroxylation}

It is generally accepted, that a dehydroxylation begins at the temperature $\sim 450{ }^{\circ} \mathrm{C}$, although the first attributes of this process identified through mechanical [5], electrical [6] properties of kaolin (or unfired porcelain mixture), the isothermal weight loss in kaolin [7] shown, that the beginning of dehydroxylation can be shifted to the temperature $\sim 420{ }^{\circ} \mathrm{C}$. A chemical equation of dehydroxylation can be represented by several ways. The chemical equations describing this process are

$$
\begin{gathered}
\mathrm{Al}_{2} \mathrm{O}_{3} \cdot 2 \mathrm{SiO}_{2} \cdot 2 \mathrm{H}_{2} \mathrm{O} \rightarrow \mathrm{Al}_{2} \mathrm{O}_{3} \cdot 2 \mathrm{SiO}_{2}+2 \mathrm{H}_{2} \mathrm{O}(\mathrm{g}), \\
\mathrm{Al}_{2} \mathrm{Si}_{2} \mathrm{O}_{5}(\mathrm{OH})_{4} \rightarrow \mathrm{Al}_{2} \mathrm{Si}_{2} \mathrm{O}_{7}+2 \mathrm{H}_{2} \mathrm{O}(\mathrm{g}) ;
\end{gathered}
$$


or considering that in a unit cell there are eight $\mathrm{OH}$ groups, which undergo the following change

or

$$
8 \mathrm{OH}^{-} \rightarrow 4 \mathrm{H}_{2} \mathrm{O}(\mathrm{g})+4 \mathrm{O}^{2-},
$$

$$
\mathrm{OH}+\mathrm{OH} \rightarrow \mathrm{H}_{2} \mathrm{O}(\mathrm{g})+\mathrm{O} .
$$

The water steam carries away $13.96 \%$ of the mass of the stechiometric kaolinite during dehydroxylation. The result of this is decreasing of the specific mass of the kaolinite from $2.64 \mathrm{~g} / \mathrm{cm}^{3}$ to $2.51 \mathrm{~g} / \mathrm{cm}^{3}$, and increasing a porosity of the kaolin from $\sim 45 \%$ to $\sim 50 \%$ [7], and increasing its specific surface area $\sim 5 \mathrm{~m}^{2} / \mathrm{g}[8]$.

Dehydroxylation occurs on the phase boundary. A mechanism of dehydroxylation includes a transport of $\mathrm{OH}^{-}$groups to the phase boundary, then the reaction of the groups on the boundary and, finally, transport of the products (molecules $\mathrm{H}_{2} \mathrm{O}$ ) to the edge of the crystal. The rate of dehydroxylation is determined by the slowest process. It was revealed, that this process is diffusion of the molecules $\mathrm{H}_{2} \mathrm{O}$ between layers of the kaolinite structure [4-13]. From this, the dehydroxylation is controlled by diffusion. The models of diffusion into cylinder (D2 model) and into sphere (D3 model) fit acceptably experimental results obtained from TGA. The model D2 is preferred because the kaolinite crystal is closer to a flat cylinder and a direction of the diffusion is radial along the layers. Activation energy of dehydroxylation for the following degree of the conversion $0<\alpha<0.65$ is $140-190 \mathrm{~kJ} / \mathrm{mol}$ $\mathrm{H}_{2} \mathrm{O}$ in dependence on size and defects of the kaolinite crystals. The smaller size have crystals and the more defects they content, the less activation energy is observed, which can decrease to $100 \mathrm{~kJ} / \mathrm{mol} \mathrm{H}_{2} \mathrm{O}[4,9,14]$. A rate of dehydroxylation is also influenced by the partial pressure of the $\mathrm{H}_{2} \mathrm{O}$ vapor $[12,13,17,18]$.

From a different perspective, there are also experimental evidences for dehydroxylation as a reaction of the $1^{\text {st }}$ order. Brindley and Nakahira came to this conclusion through isothermal TGA [19] and Anthony and Garn by the help of the gas chromatographic analysis $[17,18]$. These authors discovered that dehydroxylation may be related to a reaction of the $1^{\text {st }}$ order if $\mathrm{H}_{2} \mathrm{O}$ molecules can escape without obstacles $[17,18]$. The $1^{\text {st }}$ order dehydroxylation kinetics is regarded also in a review [20]. Dehydroxylation rate is directly proportional to the surface area of the kaolinite crystals.

Authors of $[10,21]$ assume, that homogeneous and inhomogeneous mechanisms of the dehydroxylation are possible. In the homogeneous process water is formed by reaction between adjacent $\mathrm{OH}$ groups and migrate through the crystal. A consequence is the large disruption of the crystal lattice. The tetrahedral layer remains but octahedral layer destroys and the distance between these layers decreases. Every crystal cell loses one molecule $\mathrm{H}_{2} \mathrm{O}$, which is created by the jump of $\mathrm{H}^{+}$between two neighbor $\mathrm{OH}^{-}$groups. In the inhomogeneous process migration of $\mathrm{H}^{+}$corresponding counter-migration of $\mathrm{Al}^{3+}$ and $\mathrm{Si}^{4+}$ between close microscopic regions are assumed. Water is lost from the first regions, which became micropores, and the structural continuity is preserved in the second regions, which became metakaolinte. The mechanism of the dehydroxylation was investigated in detail in [22] and it was determined that this mechanism is inhomogeneous for the temperatures lower than $455^{\circ} \mathrm{C}$. The inhomogeneous mechanism explains creation of the microporosity well.

Authors of the work [4] assume, that dehydroxylation is heterogeneous process. Not every molecule has the same probability for reaction, because the reaction is initiated in the defect places of the structure. Kinetics of dehydroxylation depends on defect density and the more perfect the structure, the higher the temperature of dehydroxylation. More present researchers regard dehydroxylation as a reaction with homogeneous mechanism.

Because of the condition that $2 / 3$ of the $\mathrm{OH}$ groups in the octahedral layer are on the surface of the layer and $1 / 3$ of the $\mathrm{OH}$ groups are inside, two difference activation energies of dehydroxylation can exist $[4,16]$. Liberation of the outer $\mathrm{OH}$ groups appears at the temperature $420-600$ ${ }^{\circ} \mathrm{C}$, and the liberation of the inner $\mathrm{OH}$ groups appears at higher temperatures as far as $850-950^{\circ} \mathrm{C}[25,26,27]$. In these works, dehydroxylation as a two-step process is proposed. Estimated activation energy of the high-temperature step is $\sim 56 \mathrm{~kJ} / \mathrm{mol} \mathrm{H}_{2} \mathrm{O}$. But it has to be said, that in spite of the theoretical possibility of the two-step dehydroxylation, neither thermogravimetry nor other experimental techniques do not show such course of the liberation of the constitutional water.

\section{Metakaolinite}

The result of dehydroxylation is a new phase called a metakaolinite. During this reaction, as XRD showed, the higher-order reflections lost their intensity and vanished in the XRD background. This result led to the opinion, that the matakaolinite can be amorphous, now a conception of the short-range order crystalline structure of metakaolinite predominates $[1,2,23,24]$. The loss of high-order reflections indicates that dehydroxylation results in structural disturbances through the breaking of unstable bonds. As a result, the degree of ordering became lower than that in kaolinite as dehydroxylation progressed. The metakaolinite does not collapse but, rather, retains a layered structure. The first attempt to compile a crystallographic model of metakaolinite was made by Brindley and Nakahira, [23, 24], who proposed ideal well-ordered lattice depicted in Fig. 2. Metakaolinite maintains the $a$ and $b$ kaolinite lattice parameters, but c-axis parameter disappears, leading to diffuse of the XRD patterns. Octahedral layer is likely to be changed more than the tetrahedral silica layer during dehydroxylation process. Presumably, the remnant oxygen and vacant anion sites rearrange as a way to lower lattice energy. The structure of metakaolinite allows the kaolinite 
to collapse to $0.63 \mathrm{~nm}$ in agreement with the measured densities of kaolinite and metakaolinite. Proposed structure of the metakaolinite shows no $\mathrm{OH}$ groups. A recent work [2] assumes the rearrangement of the oxygen and vacant sites, which gives stability to the layered structure. This rearrangement builds modulations along the c-axis in metakaolinite with a period of $0.14 \mathrm{~nm}$.

A revisited structural model of metakaolinite was proposed by MacKenzie et al. by computer simulation and nuclear magnetic resonance studies [19]. This structure accounts the presence of $11-12 \%$ residual $\mathrm{OH}$ groups, which are incorporated in the Al-O layers.

A different view on the metakaolinite structure can be found in [28]. About $22 \%$ of the crystal volume is diverted by escaping $\mathrm{H}_{2} \mathrm{O}$. That theoretically decreases the lattice parameter $c$ from the value $0.713 \mathrm{~nm}$ to $0.556 \mathrm{~nm}$ (parameters $a, b$ remain to be constant). But experimentally it was found $c=0.685 \mathrm{~nm}$. This disagreement was solved by a new model of the metakaolinite structure with high concentration of the polarized vacancies. That structure is unstable with excess of the lattice energy. This energy is released during exothermic reaction at the temperature $950{ }^{\circ} \mathrm{C}$ when the structure shrinks $\sim 20 \%$ and changes into new phase with different structure.

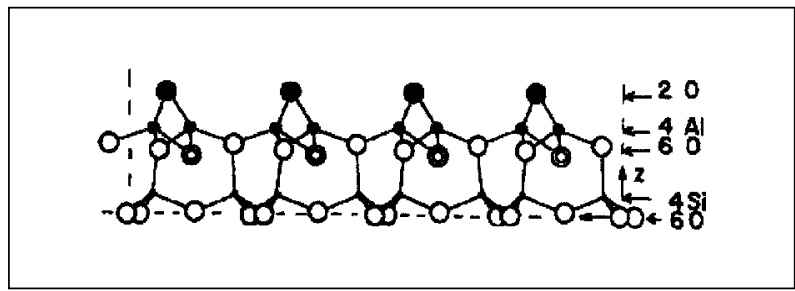

Fig. 2. Lattice of metakaolinite supposed by Brindley and Nakahira A metakaolinitrács Brindley és Nakahira szerint

\section{Conclusion}

The study of dehydroxylation of kaolin, despite of the long time of investigation and many obtained results, continues to be attractive. The cross-flow of ideas still brings new impetus for application of the new sophisticated methods and techniques, which advance our knowledge and may build our conception of dehydroxylation sequence and the metakaolinite structure.

For the present day we know these facts about dehydroxylation:

- dehydroxylation begins at the temperature $\sim 420{ }^{\circ} \mathrm{C}$;

- water steam carries away $13.96 \%$ of the mass of the stechiometric kaolinite;

- specific mass of the kaolinite decreases from $2.64 \mathrm{~g} / \mathrm{cm}^{3}$ to $2.51 \mathrm{~g} / \mathrm{cm}^{3}$;

- porosity of the kaolin increases from $\sim 45 \%$ to $\sim 50 \%$ and its specific surface area increases $\sim 5 \mathrm{~m}^{2} / \mathrm{g}$;

- dehydroxylation occurs on the phase boundary;

- kinetics of dehydroxylation depends on defect den- sity. The more perfect the structure, the higher the temperature of dehydroxylation. Activation energy of dehydroxylation for degree of the conversion $0<\alpha$ $<0.65$ is $140-190 \mathrm{~kJ} / \mathrm{mol} \mathrm{H}_{2} \mathrm{O}$ in dependence on size and defects of the kaolinite crystals. The smaller size has crystals and the more defects they content, the less activation energy is observed, which can decrease to $100 \mathrm{~kJ} / \mathrm{mol} \mathrm{H}_{2} \mathrm{O}$;

- rate of dehydroxylation is influenced by the partial pressure of the $\mathrm{H}_{2} \mathrm{O}$ vapor. The less this partial pressure, the higher rate of dehydroxylation is observed;

- it is not unambiguously stated which mechanism describes dehydroxylation. Homogeneous and inhomogenous mechanism was proposed;

- dehydroxylation can be described by the model F1, (reaction of the $1^{\text {st }}$ order) and by the model D2 or D3 (reaction controlled by diffusion). A comparison of the experimental values with theoretical values $\mathrm{F} 1$ and $\mathrm{D} 2$ (or D3) shown, that dehydroxylation mechanism can not be described by only one model in a full temperature region.

\section{Acknowledgements}

This work was supported by grant VEGA 1/3179/06.

\section{References}

[1] Chin-Yi Chen - Wei-Hsing Tuan: Evolution of mullite texture on firing tape-cast kaolin bodies. J. Amer. Ceram. Soc., 85, 2002, N5, $1121-1126$.

[2] Sujeong Lee - Youn-Joong Kim - Hi-Soo Moon: Energy-filtering electron microscopy (EF-TEM) study of a modulated structure in metakaolinite represented by a 14 modulation. J. Amer. Ceram. Soc., 86, 2003, N1, 174-176.

[3] Iqbal, Y. - Lee, W.E.: Microstructural evolution in triaxial porcelain. J. Amer. Ceram. Soc., 83, 2000, N12, 3121-3127.

[4] Čičel, B. - Novák, I. - Horváth, I.: Mineralogy and crystallochemistry of clays. SAV, Bratislava, 1981.

[5] Kozik, T. - Štubňa, I.: Mechanical strength of the ceramic material in the dehydroxylation temperature region. Silikáty, 25, 1981, N3, 237-241.

[6] Kozik, T. et al.: The temperature dependence of the electric conductivity of unfired porcelain mixture. Ceramics-Silikáty, 36, 1992, $\mathrm{N} 2,69-72$.

[7] Knovel International Critical Tables, Physics, Chemistry and Technology. ( $1^{\text {st }}$ electronic edition, 2003), www.knovel.com/knovel/databook/pdf/735/44927_05.9 pdf.

[8] Norton, F. H.: Fine ceramics - technology and applications. McGraw-Hill Book Co., New York, 1970 (s. 240-243).

[9] Horváth, I.: Sedlec kaolinite dehydroxylation kinetics. In: Proc. $7^{\text {th }}$ Conf. Clay Mineral and Petrol. Karlovy Vary, 1976, 121-127.

[10] Hanykýŕ, V. Kutzendoerfer, J.: Technologie keramiky. Silis Praha a Vega Hradec Králové, 2000,

[11] Hanykýř, V. - Maryška, M. - Bouška, P. - Pume, D.: Vznik keramického střepu a jeho stárnutí. Silika, 14, 2004, č. 5-6, 130-135.

[12] Brindley, G. W. - Sharp, J. H. - Patterson, J. H. - Narahari, B. N.: Kinetics and mechanism of dehydroxylation process, I. temperature and vapor pressure dependence on dehydroxylation of kaolinite. The Amer. Mineralogist, 52, 1967, N1-2, 201-211.

[13] Toussaint, F. - Fripiat, J. J. - Gastuche, M. C.: Dehydroxylation of kaolinite, I, kinetics. J. Phys. Chem., 67, 1963, N1, 26-30.

[14] Horváth, I. - Kranz, G.: Thermoanalytic study of the high-tempe- 
rature dehydratation of kaolins with different degree of the order. Silikáty, 24, 1980, N2, 149-160.

[15] Sánchez-Soto, P. et al.: Effects of dry grinding on the structural changes of kaolinite powders. J. Ame7r. Ceram. Soc., 83, 2000, N7, 1649-1657.

[16] Pampuch, R.: Infrared study of thermal transformation of kaolinite and the structure of metakaolin. Prace mineral., 6, 1966, 53-70.

[17] Garn, P. D. - Anthony, G. D.: The questionable kinetics of kaolin dehydroxylation. J. Thermal Analysis, 1, 1969, N1, 29-33.

[18] Anthony, G. D. - Garn, P. D.: Kinetics of kaolinite dehydroxylation. J. Amer. Ceram. Soc., 57, 1974, N3, 132-135.

[19] Brindley, G. W. - Nakahira, M.: Kinetics of dehydroxylation of kaolinite and halloysite. J. Amer. Ceram. Soc., 40, 1957, N10, 346-350.

[20] Carty, W. M. - Senapati, U.: Porcelain - raw materials, phase evolution, and mechanical behavior. J. Amer. Ceram. Soc., 81, 1998, N1, 3-20.

[21] MacKenzie, K. J. D.: Feats of clay, or mineral chemistry revisited. Chemistry in New Zealand, 1978, N3, 8-12.
[22] Suitch, P. R.: Mechanism for the dehydroxylation of kaolinite, dickite and nackrite from room temperature to $455^{\circ} \mathrm{C}$. J. Amer. Ceram. Soc., 69, 1986, N1, 61-65.

[23] Brindley, G. W. - Nakahira, M.: The kaolinite-mullite reaction series: I, A survay of outstanding problems. J. Amer. Ceram. Soc., 42, 1959, N7, 311-314.

[24] Brindley, G. W. - Nakahira, M.: The kaolinite-mullite reaction series: II, Metakaolin. J. Amer. Ceram. Soc., 42, 1959, N7, 314-318.

[25] Kiselev, I. M.: Firing of kaolin and investigation of fired products. PhD thesis stored in ONIITECHIM, Čerkassy, 1978, No. 1762178.

[26] Živanovič, B. - Janovič, O.: Dehydroxylation of kaolinite. Hem. Ind. 32, 1978, N8, 512-516.

[27] Poppe, L. - Gabor, M. - Wajand, J. - Szabó, Z.: Two-step dehydroxylation of the kaolinite. In: Proc. $1^{\text {st }}$ Symp. Thermal Anal., Salford 1976, 332-335.

[28] Freund, F.: Kaolinite-metakaolinite, a model of a solid with extremely high lattice defect concentration. Ber. Deutsche Keram. Ges., 44, 1967, N4, 5-13. 